\title{
Breadth and magnitude of antigen-specific antibody responses in the control of plasma viremia in simian immunodeficiency virus infected macaques
}

Bapi Pahar ${ }^{1,2^{*}}$ (D), Carys S. Kenway-Lynch ${ }^{1}$, Preston Marx ${ }^{3}$, Sudesh K. Srivastav ${ }^{4}$, Celia LaBranche ${ }^{5}$, David C. Montefiori ${ }^{5}$ and Arpita Das ${ }^{3}$

\begin{abstract}
Background: Increasing evidence suggests an unexpected potential for non-neutralizing antibodies to prevent HIV infection. Consequently, identification of functional linear B-cell epitopes for HIV are important for developing preventative and therapeutic strategies. We therefore explored the role of antigen-specific immune responses in controlling plasma viremia in SIV infected rhesus macaques.
\end{abstract}

Methods: Thirteen rhesus macaques were inoculated either intravaginally or intrarectally with $\operatorname{SIV}_{\text {MAC }} 251$. Peripheral blood CD4+ T-cells were quantified. Plasma was examined for viremia, antigen specific $\lg G$, $\lg A$ and $\lg M$ binding responses and neutralizing antibodies. Regions containing binding epitopes for antigen-specific lgG, IgM and IgA responses were determined, and the minimum size of linear Envelope epitope responsible for binding antibodies was identified.

Results: The presence of neutralizing antibodies did not correlate the outcome of the disease. In a few SIV-infected macaques, antigen-specific lgG and IgM responses in plasma correlated with decreased plasma viremia. Early induction and the breadth of antigen-specific lgG responses were found to be significantly correlated with the control of plasma viral load. Immunoglobulin classes share similar functional linear B-cell epitopes. SIV-specific linear envelope B-cell epitopes were found to be 12 amino-acids in length.

Conclusions: Early induction of combination of peptide-specific lgG responses were found to be responsible for the control of plasma viral load and indicative of disease outcome in SIV-infected rhesus macaques and might be important for the development of therapeutic strategies for control or prevention of HIV/AIDS.

Keywords: Antibody, Breadth, Correlate of protection, Neutralizing antibodies, Peptides, Rhesus macaque, SIV, SIV-antigens

\section{Background}

HIV-1 infection is associated with polyclonal B-cell activation, hypergammaglobulinemia, the presence of immature/ transitional CD10+ or exhausted CD27 negative B-cells in blood [1, 2], exhaustion of tissue-like memory (CD20(hi)/ CD27(-)/CD21(lo)) B-cells [3], loss of total B-cell populations $[4,5]$, and nonspecific switching from IgM to IgG, IgA and IgE responses. Our recent data demonstrated

\footnotetext{
* Correspondence: bpahar@tulane.edu

'Division of Comparative Pathology, Tulane National Primate Research Center, 18703 Three Rivers Road, Covington, LA 70433, USA

${ }^{2}$ Tulane University School of Medicine, New Orleans 70112, LA, USA

Full list of author information is available at the end of the article
}

defective memory $(\mathrm{CD} 21+\mathrm{CD} 27+)$ B-cell proliferation in selective tissues in simian immunodeficiency virus (SIV)infected macaques $[6,7]$. Therefore, the maintenance of normal and effective humoral immune responses may be the key to the prevention and control of HIV/SIV infection. Recent reports emphasize that HIV-specific antibodies (Abs), instead of T-cell responses, may correlate better with protection in seronegative partners of HIV-1 infected individuals [8]. Moreover, other emerging studies demonstrate a correlation between anti-HIV antibodies and protection from infection, although these protective Abs are not strictly neutralizing in vitro [9]. Furthermore, lymphocytic choriomeningitis virus infection in the mouse 
model has also shown that non-neutralizing Abs elicited early in infection are capable of binding to the virus and limiting it's spread [10].

B-cell epitopes are described either as conformational (discontinuous, assembled) epitopes where multiple discontinuous amino-acids (aa) segments are folded to produce a unique conformational epitope complementary to the antibody, termed a contact epitope [11-14], or linear epitopes (continuous, sequential) where epitopes do not incorporate protein folding and can be represented by linear peptide sequence [15]. The continuous maturation of the immune response following SIV infection emphasizes the need to study the generation of SIV-specific Ab responses, antigen-antibody binding efficacy, and their potential importance in regulating disease progression.

The present study was designed to determine the importance of total immunoglobulin, antigen-specific immunoglobulin responses against whole viral lysate (WVL), peptides corresponding to Env, Gag, Nef, and Tat and neutralizing antibodies (NAbs) in controlling plasma viral load (pVL) in SIV $_{\text {MAC }} 251$ infected rhesus macaques (RMs). Regions containing binding epitopes for antigen-specific IgG, IgM and IgA responses during different stages of SIV infection were determined, and the minimum size of linear Env epitope responsible for binding Abs was identified. Our findings suggest that conformational IgG and IgM responses as well as breadth of different peptide-specific functional IgG responses are indicative of disease outcome. The presence of NAbs against neutralization-sensitive and resistant pseudovirus did not predict the outcome of the disease.

\section{Methods}

\section{Animals}

All animals in this study were housed at the Tulane National Primate Research Center (TNPRC) in accordance with the standards incorporated in the Guide for the Care and Use of Laboratory Animals [16]. All of TNPRC animal housing meets the Laboratory and Animal Biosafety Level 2+ requirements recommended for hepatitis, AIDS, and other viral agents related studies in the $\mathrm{CDC} / \mathrm{NIH}$ publication "Biosafety in Microbiological and Biomedical Laboratories". The Tulane Institutional Animal Care and Use Committee (IACUC) of the TNPRC approved all animal procedures related to this manuscript. The TNPRC is fully accredited by the Association for the Assessment and Accreditation of Laboratory Animal Care (Animal Welfare Assurance A-4499-01). Virus inoculation, sample collections from animals were performed under the direction of veterinarians. Every effort was made to avoid unnecessary discomfort and pain to animals. At the TNPRC, animal discomfort or pain was alleviated by appropriate use of anesthetic medications.
Rhesus macaques were sedated with ketamine $(10 \mathrm{mg} /$ $\mathrm{kg}$ body weight) whenever they were removed from their home cage for routine blood collection, physical examinations or other minor procedures. Animals were euthanized humanely using the standard method of euthanasia for nonhuman primates, where animals were euthanized using Telazol and buprenorphine followed by a lethal intravenous dose of sodium pentobarbital. This method was consistent with the recommendation of the American Veterinary Medical Association Guidelines.

\section{Animal and tissue sampling}

Thirteen adult Indian RMs (Macaca mulatta), initially negative for SIV, HIV-2, type D retrovirus and simian T-cell leukemia virus 1 infection were inoculated with 300-500 TCID $_{50}$ of SIV $_{\text {MAC }} 251-C X$ intravaginally (Ivag) or intrarectally (IR) (Table 1). Two out of 13 RMs were positive for Mamu-A*01 and majority were negative for Mamu-B*17 alleles. Mamu-A*01 and Mamu-B*17 alleles were found to be linked with lower viral set points and slow disease progression in SIV infected RMs [17-20]. However, the independent presence of Mamu-B*17 allele does not predict the outcome of SIV infection [21]. Intravaginally inoculated female macaques were treated with depot medroxyprogesterone acetate (30 $\mathrm{mg}$ intramuscularly) 28d prior to SIV exposure [22]. Sodium heparin and EDTA peripheral blood (PB) were collected at sequential time points for analysis described below.

\section{Plasma viral load quantification}

Plasma viral RNA was quantified either by bDNA signal amplification assay for IR macaques (Siemens Diagnostics, USA) [22, 23] or by quantitative RT-PCR assay for Ivag macaques (Wisconsin National Primate Research Center Virology Core laboratory) [24, 25]. The lower limit of RNA detection for bDNA and RTPCR assays were 125 and 60 SIV-RNA copies/ml of plasma respectively.

\section{Peripheral blood T-cell immunophenotyping}

PB T-cell immunophenotyping was performed using anti-CD3-FITC (SP34-2), anti-CD4-APC (L200) and anti-CD8-PE (RPA-T8) monoclonal antibodies (MAbs) obtained from BD Biosciences as reported earlier [5, 26]. At least 20,000 events were collected by gating on lymphocytes. Data were acquired in a BD LSRII flow cytometer within $24 \mathrm{~h}$ after staining and analyzed further using FlowJo software (TreeStar Inc.) [5, 27]. Absolute count of CD4+ T-cell population was calculated using flow cytometry and $\mathrm{CBC}$ data. 
Table 1 List of adult Indian rhesus macaques examined

\begin{tabular}{|c|c|c|c|c|c|c|c|c|}
\hline Route & $\begin{array}{l}\text { Animal } \\
\text { Number }\end{array}$ & $\begin{array}{l}\text { Age } \\
\text { (Years) }\end{array}$ & Sex ${ }^{a}$ & $\begin{array}{l}\operatorname{SIV}_{\text {MAC }} 251 \\
\text { Dosage } \\
\left(\operatorname{TCID}_{50}{ }^{b}\right)\end{array}$ & $\begin{array}{l}\text { Mamu-A*01 } \\
\text { Allele }\end{array}$ & $\begin{array}{l}\text { Mamu B*17 } \\
\text { Allele }\end{array}$ & Progressor & Major Pathological Findings \\
\hline \multirow[t]{6}{*}{ Intravaginal (Ivag) } & BC35 & 12.0 & $\mathrm{~F}$ & 300 & - & ND & - & - \\
\hline & CL86 & 10.4 & $\mathrm{~F}$ & 500 & - & ND & + & $\begin{array}{l}\text { Severe lymphoid hyperplasia and dysplasia in } \\
\text { spleen, all lymph nodes, tonsil, and many other } \\
\text { organs; Mild intestinal pneumonia }\end{array}$ \\
\hline & CL87 & 10.0 & $\mathrm{~F}$ & 300 & - & ND & - & - \\
\hline & DE50 & 9.4 & $\mathrm{~F}$ & 500 & - & - & + & Generalized amyloidosis and lymphoid hyperplasia \\
\hline & FK88 & 5.9 & $\mathrm{~F}$ & 500 & - & - & + & $\begin{array}{l}\text { Mild to moderate lymphoid hyperplasia and } \\
\text { dysplasia in spleen, multiple lymph nodes and } \\
\text { organs }\end{array}$ \\
\hline & GN91 & 3.8 & $\mathrm{~F}$ & 500 & - & - & - & - \\
\hline \multirow[t]{7}{*}{ Intrarectal (IR) } & AE14 & 8.0 & M & 500 & - & - & + & $\begin{array}{l}\text { Amyloid deposits in the liver; small number of } \\
\text { pneumocystis and SIV giant cells in lung; } \\
\text { Cryptosporidium infection in small intestine }\end{array}$ \\
\hline & AP09 & 7.3 & M & 500 & + & - & - & - \\
\hline & AP64 & 7.0 & M & 500 & - & - & - & - \\
\hline & $B G 21$ & 6.3 & M & 500 & - & - & - & - \\
\hline & N107 & 12.4 & M & 500 & - & - & - & - \\
\hline & P205 & 11.4 & $\mathrm{~F}$ & 500 & - & - & + & $\begin{array}{l}\text { Amyloidosis in the small intestine and enterocolitis; } \\
\text { lesions in lung are typical of viral pneumonia with } \\
\text { presence of SIV giant cells }\end{array}$ \\
\hline & T153 & 9.5 & $\mathrm{~F}$ & 500 & + & - & - & - \\
\hline
\end{tabular}

${ }^{\mathrm{a}} \mathrm{F}$ and $\mathrm{M}$ denote female and male respectively; ${ }^{\mathrm{b}} \mathrm{TCID}_{50}$ : Tissue culture infectivity dose at 50\%; ND: not done; " + " and "-" denotes positive and negative results respectively for the respective column

\section{Neutralization assay}

Neutralizing antibody (NAb) activity was measured in 96-well culture plates by using Tat-regulated luciferase (Luc) reporter gene expression to quantify reductions in virus infection in TZM-bl cells against the neutralization-sensitive $\operatorname{SIV}_{\mathrm{MAC}} 251.6$ and the neutralization-resistant SIV $_{\text {MAC }} 251.30$ pseudoviruses, using MLV-pseudotyped virus as a negative control for non-specific virus inhibition as described previously [28]. TZM-bl cells were obtained from the NIH AIDS Research and Reference Reagent Program, as contributed by John Kappes and Xiaoyun Wu. Heat inactivated plasma samples were diluted over a range of $1: 20$ to $1: 43740$ in cell culture medium and pre-incubated with virus $(\sim 150,000$ relative light unit equivalents) for $1 \mathrm{~h}$ at $37^{\circ} \mathrm{C}$ before addition of cells. Following a $48 \mathrm{~h}$ incubation, cells were lysed and Luc activity determined using a microtiter plate luminometer and BriteLite Plus Reagent (Perkin Elmer). Neutralization titers are the sample dilution at which relative luminescence units (RLU) were reduced by $50 \%$ compared to RLU in virus control wells after subtraction of background RLU in cell control wells.

\section{Measurement of antigen-specific and total immunoglobulin responses}

Antigen-specific IgG, IgA and IgM were detected in plasma using ELISA as previously described [5, 29, 30]. Purified SIV $_{\text {MAC }} 251$ WVL was used as coating antigen ( $5 \mu \mathrm{g} / \mathrm{ml}$, Applied Biosystems) to quantify antibody responses against conformational/discontinuous epitopes. Total IgG, IgM and IgA concentrations were measured by ELISA as previously described [5, 7], where plates were coated with either anti-monkey IgG Fc/7s (Accurate Chemicals), IgM Fc (Accurate Chemicals) or IgA Fc (Alpha Diagnostic International) Abs. All samples were assayed in duplicate with appropriate positive and negative controls. For quantification of WVL-specific and total immunoglobulin responses, rhesus IgG, IgA (NIH-Nonhuman Primate Reagent Resource) and IgM (Fitzgerald Industries International) standards were used. Nonlinear regression using a sigmoidal dose-response variable slope model was used to interpolate concentrations from the standard curve. For WVL-specific Ig responses, positive values had to exceed the mean $+2 \mathrm{SD}$ of all animal's preinfection readings for a specific antigen at absorbance $490 \mathrm{~nm}$. To increase stringency and to account for variation between animals, the absorbance values for each 
individual animal also had to exceed two times the value for the specific animal prior to infection to be classified as positive.

\section{Measurement of peptide-specific immunoglobulin responses}

SIV-Env (catalog- 6883), SIV-Gag (catalog- 6204), SIVNef (catalog- 8762), and SIV-Tat (catalog- 6207) 15-mers with 11-aa overlap peptides (NIH AIDS Research and Reference Reagent Program) were used as coating antigen. Plates were coated with peptide pools (PPs, 4-10 peptides per pool, $5 \mu \mathrm{g} / \mathrm{ml}$ of each peptide in $0.1 \mathrm{M}$ sodium carbonate monohydrate, $\mathrm{pH} 9.6$ ) to determine antibody responses generated against linear/continuous epitopes by ELISA as described earlier [5, 29, 30]. For all peptide-specific ELISA values, the positive responses were determined as specified above for WVL-specific responses. Cumulative OD values were calculated by the summation of OD/490 values for each positive peptide pool, after subtraction of the pre-infection value for each peptide pool in a protein.

\section{Statistical analysis}

Statistical significance for immunoglobulin quantitation data was determined using a one-way ANOVA. The Bonferroni method was used as a post hoc multiple comparison test for all means. Statistical differences between groups were tested using a two-tailed unpaired t-test. Pearson coefficient of determination analysis was performed to calculate correlation between pVLs and immunoglobulin responses and between pVLs and breadth of antigen-specific antibody responses using SAS software (version 9 in a windows environment). For all analyses, $\mathrm{P}$ values $<0.05$ were considered significant.

\section{Results}

Plasma viral load and peripheral CD4+ count demonstrate the progression of SIV infection in SIV-infected macaques Male to female/female to male and male to male sexual transmission via intravaginal and intrarectal route respectively are responsible for 75-85\% of the HIV transmission [31]. In this study, we have used two groups of animals inoculated via Ivag (represents male to female transmission) or IR (represents male to male transmission) route to determine whether the inoculation route had any effect in regulating antigen-specific antibody and neutralizing antibody responses. We were also interested to determine whether the inoculation route had any impact on the breadth of immune responses. In all SIV-infected RMs, peak plasma viral replication ( $\log _{10}$ 6.3-7.8 RNA copies/ml of plasma) was detected between 14 and 21 day post infection (dpi, Fig. 1a). Only one animal GN91 was able to control pVL to approximately $1 \times$ $10^{3}$ RNA copies/ml of plasma following the initial peak of viremia (Fig. 1), whereas the remaining animals had plasma SIV-RNA greater than 10,000 copies $/ \mathrm{ml}$ of plasma. Several of these animals (CL86, DE50, FK88, AE14, and P205) progressed to AIDS rapidly and were euthanized accordingly (Table 1 ). There were no difference in the mean viral set points (measured 25 to 95dpi) between Ivag and IR infected RMs.

Following SIV $_{\text {MAC }} 251$ infection, absolute CD4 count in peripheral blood decreased rapidly in the majority of the animals except GN91, in which CD4+ T-cell count decreased after 150dpi (Fig. 1a). Animal N107 had a low peripheral CD4+ T-cell count from the beginning compared to other macaques and by $18 \mathrm{dpi}$ the CD4+ T-cell count was below 200 cells/ $\mu$ l of blood and remained low throughout this study. The absolute CD4+ T-cell counts do not completely reflect the status of pVL as AE14 and BG21 had similar patterns of CD4+ T-cell count in peripheral blood, however the plasma viral load in AE14 remained 2.2 log higher than the viral load in BG21 from 68dpi onwards.

\section{Neutralizing antibody titers did not predict the disease outcome or the progression of disease}

All thirteen RMs were selected to perform NAb assays at several different time points after SIV infection (Table 2). Neutralization of the highly neutralizationsensitive Tier 1A virus, SIVmac251.6 was detectable in all animals by 25-27 days post-infection and rose to very high titers over the time course of the samples received. Out of a total of 13 RMs, neutralization of SIVmac251.30, which exhibits an insensitive Tier 3 neutralization phenotype that more closely approximates the infecting virus, was detected at 42 and/or 95dpi in 4 RMs and at 257dpi in 1 RM. A few of the titers were fairly high in RMs AE14, AP09, CL87 and P205. However, AE14 and P205 progressed to AIDS rapidly despite the presence of NAb titers against neutralizationresistant SIVmac251.30 pseudovirus (Table 2). We did not observe any difference in Nab titers between Ivag and IR infected RMs.

\section{In a few SIV-infected macaques, antigen-specific IgG and} IgM responses in plasma correlated with decreased plasma viremia

Total and WVL-specific IgG, IgM and IgA responses were measured in both IVag and IR inoculated SIV infected macaques (Fig. 2 and Additional file 1: Table S1). Total IgG concentration remained largely consistent (IVag: 2989-9367 $\mu \mathrm{g} / \mathrm{ml}$; IR: 1533-4028 $\mu \mathrm{g} / \mathrm{ml}$ ) while SIV-specific IgG responses increased significantly during the course of SIV infection in both IVag and IR infected macaques (geometric mean values $1084 \mu \mathrm{g} / \mathrm{ml}$ at 257 days post infection (dpi) and $334 \mu \mathrm{g} / \mathrm{ml}$ at $272 \mathrm{dpi}$ in IVag and IR infection respectively; Fig. 2). Increased 
A

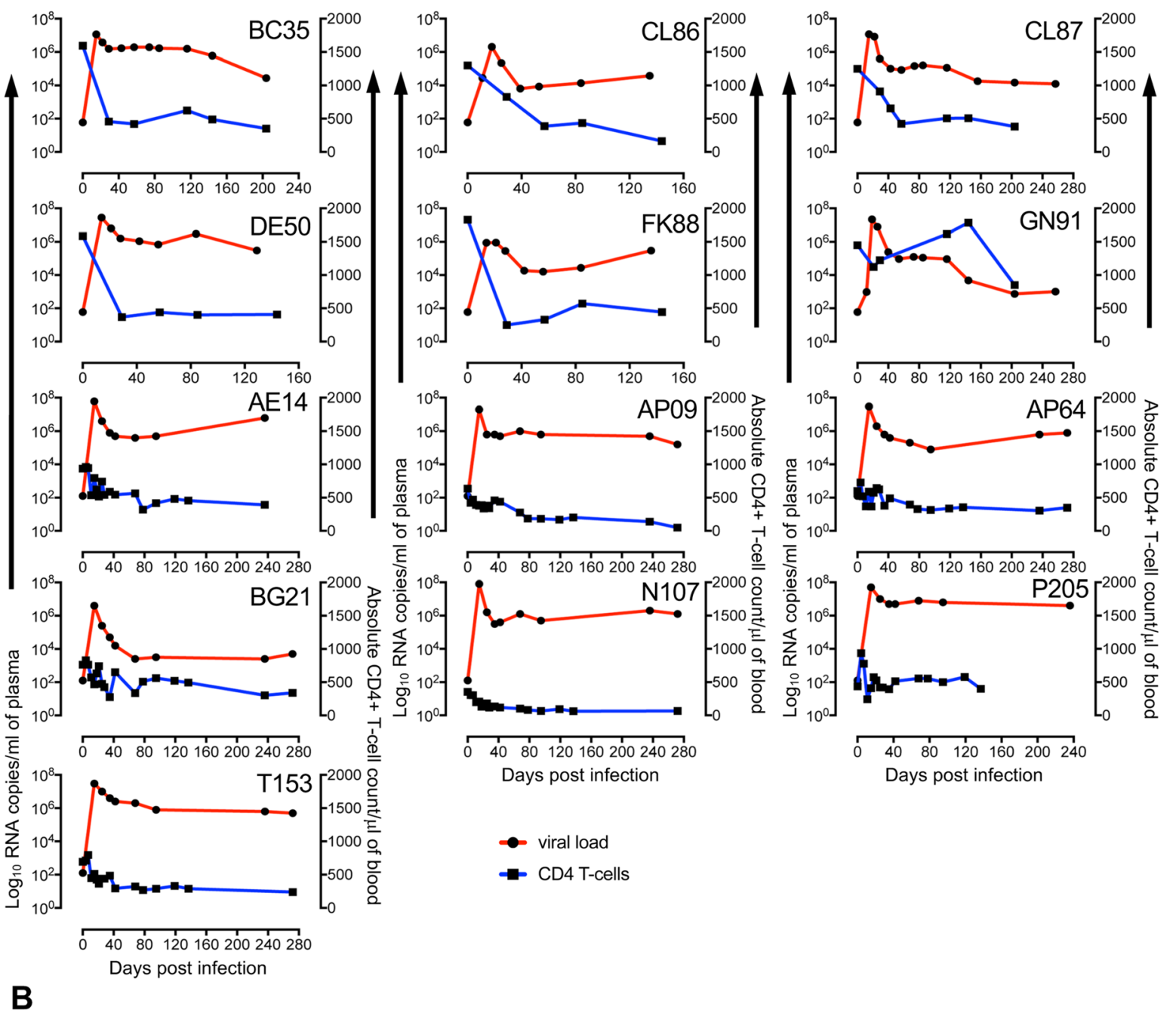

\begin{tabular}{|c|c|c|c|c|c|c|c|c|c|c|c|c|c|c|}
\hline \multirow{2}{*}{\multicolumn{2}{|c|}{ Animal }} & \multicolumn{3}{|c|}{ Total } & \multicolumn{2}{|c|}{ WVL-specific } & \multicolumn{4}{|c|}{ Peptide specific IgG } & \multicolumn{2}{|c|}{ Peptide specific IgM } & \multicolumn{2}{|c|}{ Peptide specific $\lg A$} \\
\hline & & $\lg G$ & $\lg M$ & $\lg A$ & $\lg G$ & $\lg M$ & Env & Gag & Nef & Tat & Gag & Tat & Env & Gag \\
\hline \multirow[t]{2}{*}{$\overline{\text { BC35 }}$} & $\bar{R}$ & -0.781 & 0.417 & -0.070 & -0.964 & 0.220 & -0.900 & -0.989 & -0.909 & 0.170 & ND & 0.144 & -0.409 & ND \\
\hline & $P$ & 0.008 & NS & NS & $<0.001$ & NS & $<0.001$ & 0.001 & $<0.001$ & NS & ND & NS & NS & ND \\
\hline \multirow[t]{2}{*}{ CL86 } & $\mathrm{R}$ & -0.082 & 0.675 & -0.125 & -0.202 & 0.524 & -0.874 & -0.702 & ND & ND & -0.275 & ND & -0.539 & -0.371 \\
\hline & $\mathrm{P}$ & NS & NS & NS & NS & NS & 0.023 & NS & ND & ND & NS & ND & NS & NS \\
\hline \multirow[t]{2}{*}{ CL87 } & $\mathrm{R}$ & -0.432 & 0.542 & 0.244 & -0.728 & -0.658 & -0.788 & -0.231 & -0.660 & -0.402 & ND & ND & -0.106 & -0.049 \\
\hline & $\mathrm{P}$ & NS & NS & NS & 0.017 & 0.039 & 0.007 & NS & 0.038 & NS & ND & ND & NS & NS \\
\hline \multirow[t]{2}{*}{ DE50 } & $\mathrm{R}$ & -0.873 & -0.361 & 0.344 & -0.694 & 0.529 & -0.818 & -0.141 & ND & ND & -0.192 & ND & -0.180 & -0.003 \\
\hline & $\mathrm{P}$ & 0.023 & NS & NS & NS & NS & 0.047 & NS & ND & ND & NS & ND & NS & NS \\
\hline \multirow[t]{2}{*}{ FK88 } & $R$ & 0.073 & 0.467 & -0.277 & 0.077 & -0.421 & -0.946 & -0.419 & ND & ND & 0.443 & ND & -0.688 & -0.593 \\
\hline & $P$ & NS & NS & NS & NS & NS & 0.004 & NS & ND & ND & NS & ND & NS & NS \\
\hline \multirow[t]{2}{*}{ GN91 } & $\mathrm{R}$ & 0.222 & -0.382 & 0.407 & -0.830 & -0.745 & -0.940 & -0.929 & -0.846 & -0.847 & 0.366 & 0.104 & -0.514 & 0.038 \\
\hline & $\mathrm{P}$ & NS & NS & NS & 0.003 & 0.013 & $<0.001$ & $<0.001$ & 0.002 & 0.002 & NS & NS & NS & NS \\
\hline \multirow[t]{2}{*}{$\mathrm{AE} 14$} & $R$ & -0.805 & -0.887 & -1.000 & -0.751 & -0.840 & ND & ND & ND & ND & -0.573 & -0.986 & ND & ND \\
\hline & $P$ & NS & 0.045 & 0.013 & NS & NS & ND & ND & ND & ND & NS & 0.002 & ND & ND \\
\hline \multirow[t]{2}{*}{ AP09 } & $\mathrm{R}$ & -0.916 & -0.213 & -0.573 & -0.923 & -0.100 & -0.871 & -0.888 & ND & ND & ND & ND & -0.953 & -0.881 \\
\hline & $P$ & 0.010 & NS & NS & 0.009 & NS & 0.024 & 0.018 & ND & ND & ND & ND & 0.003 & 0.021 \\
\hline \multirow[t]{2}{*}{ AP64 } & $\mathrm{R}$ & 0.165 & -0.166 & 0.910 & -0.590 & 0.236 & -0.506 & -0.871 & ND & ND & -0.385 & ND & 0.157 & ND \\
\hline & P & NS & NS & NS & NS & NS & NS & NS & ND & ND & NS & ND & NS & ND \\
\hline \multirow[t]{2}{*}{ BG21 } & $\mathrm{R}$ & -0.317 & -0.021 & 0.169 & -0.417 & 0.824 & -0.411 & -0.457 & -0.388 & -0.315 & -0.401 & -0.335 & -0.378 & -0.147 \\
\hline & $P$ & NS & NS & NS & NS & 0.044 & NS & NS & NS & NS & NS & NS & NS & NS \\
\hline \multirow[t]{2}{*}{ N107 } & $\mathrm{R}$ & -0.209 & -0.482 & -0.946 & -0.265 & -0.342 & -0.225 & ND & ND & ND & 0.173 & 0.173 & -0.460 & -0.899 \\
\hline & P & NS & NS & NS & NS & NS & NS & ND & ND & ND & NS & NS & NS & 0.015 \\
\hline \multirow[t]{2}{*}{ P205 } & $\mathrm{R}$ & 0.643 & -0.356 & 0.002 & -0.892 & 0.678 & -0.672 & ND & ND & ND & 0.016 & -0.349 & ND & ND \\
\hline & $P$ & NS & NS & NS & NS & NS & NS & ND & ND & ND & NS & NS & ND & ND \\
\hline \multirow[t]{2}{*}{ T153 } & $\mathrm{R}$ & -0.686 & 0.414 & -0.905 & -0.789 & 0.198 & -0.916 & -0.843 & ND & ND & 0.845 & ND & -0.974 & -0.668 \\
\hline & $\mathrm{P}$ & NS & NS & NS & NS & NS & 0.010 & 0.035 & ND & ND & 0.034 & ND & 0.001 & NS \\
\hline
\end{tabular}

Fig. 1 (See legend on next page.) 
(See figure on previous page.)

Fig. 1 a Plasma viral load and absolute CD4+ T-lymphocyte counts over the course of 257 days for intravaginally (Ivag, $n=6$, upper rows) and 272 days for intrarectally (IR, $n=7$, bottom rows) $\operatorname{SIV}_{\text {MAC }} 251$ inoculated macaques were shown. One macaques, GN91 was able to maintain plasma viral load to approximately $1 \times 10^{3}$ RNA copies/ml of plasma following the initial peak of infection. The remaining macaques retained a high viral load throughout infection amongst which CL86, DE50, FK88, AE14 and P205 progressed to AIDS rapidly and were euthanized accordingly. Note GN91 was able to preserve peripheral CD4+ T-cell population after SIV infection for upto 150dpi. b Pearson coefficient of determination analysis

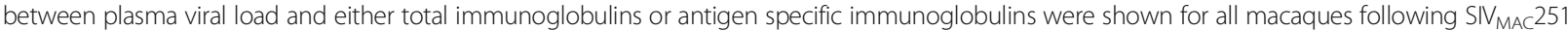
inoculation for all time points. No significant correlation between plasma viral load and total or antigen-specific immunoglobulin responses were detected in two macaques (AP64 and P205) for all time specified above. Additionally, no significant correlations were found for WVL-specific lgA or peptide-specific IgM for Env and Nef. No Tat or Nef-specific IgA responses were detected. R and $\mathrm{P}$ denote Pearson $\mathrm{R}$ and probability values respectively for each row when correlated with plasma viral load. NS denotes non-significant P-value $(p>0.05)$. ND denotes a correlation cannot be calculated. Significant correlation values were shown in bold numbers

SIV-specific IgG responses in chronic infection correspond with increased peptide-specific IgG responses in both groups. Total IgM concentration also did not vary significantly throughout the course of infection (IVag: 550-1777 $\mu \mathrm{g} / \mathrm{ml}$; IR: $1503-3393 \mu \mathrm{g} / \mathrm{ml}$; Additional file 1: Table S1). However, SIV infected macaques showed an early peak in SIV-specific IgM concentrations in acute infection (Ivag: geometric mean value $1.1 \mu \mathrm{g} / \mathrm{ml}$ at 27dpi; IR: mean value $0.7 \mu \mathrm{g} / \mathrm{ml}$ at $25 \mathrm{dpi}$; Fig. 2) that decreased at later time points. SIV-specific IgM concentrations were lower in animals infected via the IR route, however, the trend between the two inoculation routes remained same. Total IgA responses varied nonsignificantly throughout infection (IVag: 632-1388 $\mu \mathrm{g} /$ $\mathrm{ml}$; IR: 797-1093 $\mu \mathrm{g} / \mathrm{ml}$; Additional file 1: Table S1). However, SIV-specific IgA responses were detected in 5 out of 6 Ivag infected RMs and the level peaked at 73dpi. AE14 from IR infected RMs did not generate WVL-specific IgA responses and the overall IgA titer in rest of the IR infected animals was lower than Ivag infected RMs (Fig. 2).

Pearson coefficient of determination analysis was performed to determine correlation between pVLs and immunoglobulin responses (20dpi to $257 \mathrm{dpi}$ and $25 \mathrm{dpi}$ to 272dpi for Ivag and IR RMs respectively, Fig. 1b) as reported earlier [32]. Total Ab responses in four (BC35, DE50, AE14 and AP09) out of thirteen macaques were negatively correlated with $\mathrm{pVLs}$ suggesting that total IgG, IgM or IgA had minimal role in controlling $\mathrm{pVL}$ (Fig. 1b). Similarly WVL-specific Ab responses in four (BC35, CL87, GN91 and AP09) out of thirteen RMs were negatively correlated with pVLs suggested that WVL-specific IgG or IgM also had minimal role in controlling pVL (Fig. 1b).

\section{Combination of different peptide-specific IgG responses} found to correlate with the control of plasma viral load Similar to WVL-specific immunoglobulin responses, peptide-specific immunoglobulin responses measured by cumulative OD values were also correlated with pVLs for all RMs to determine if any of the peptide-specific responses may represent a key predictor for the control of plasma viremia. Cumulative IgG responses against Env, Gag, Nef and Tat linear peptides show statistically significant negative correlations in eight, four, three and one RM respectively (Fig. 1b). RM GN91 maintained pVL to approximately $10^{3}$ RNA copies $/ \mathrm{ml}$, where Env, Gag, Nef and Tat specific IgG responses significantly upregulated, which might be playing a key role in controlling pVL. Significant negative correlations between Env-specific IgG responses and pVL in three disease progressing RMs (CL86, DE50 and FK88, Table 1) suggested that single antigen-specific responses were not adequate to control $\mathrm{pVL}$ and/or the disease progression and a combination of different peptide-specific IgG responses might be important in controlling pVL. Despite several significant negative correlations detected between antigen-specific IgM and IgA responses and pVLs, these independent responses did not predict the disease outcome (Fig. 1b). The breadth of IgG responses (IgG responses against antigens like Env, Gag, Nef and/or Tat) were also correlated with pVLs in all animals (Fig. 3). One (GN91) out of total 13 RMs had significant negative correlation between $\mathrm{pVL}$ and the number of antigen responses $(r=-0.64$, p-value $=0.035$; Fig. $3 \mathrm{~b})$, which suggested that breadth of antibody responses had an impact in controlling pVL. Infact, three (Env, Gag and Nef) antigen-specific IgG responses in GN91 were detected as early as $55 \mathrm{dpi}$ and by $126 \mathrm{dpi}$ IgG responses were prevalently detected against all four antigens (Env, Gag, Nef and Tat) and remained high throughout the time point of this study (Fig. 3a). No other animals had such early and increased breadth of IgG responses detected in this study. The breadth of IgG responses was evident more in Ivag compared to IR infected RMs where all Ivag animals had two or more antigen-specific IgG responses detected (Fig. 3a). AE14 RM from IR group had shown no detectable antigen-specific responses upto 236dpi. Another two RMs (N107 and P205) from IR group had shown selective Envspecific IgG responses throughout the study period. No significant correlation was detected between breadth of IgM or IgA responses and pVLs in any of these animals. 


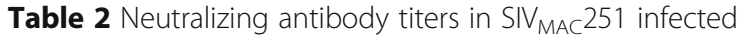
macaques

\begin{tabular}{|c|c|c|c|c|}
\hline \multirow[t]{2}{*}{ Route } & \multirow{2}{*}{$\begin{array}{l}\text { Animal } \\
\text { Number }\end{array}$} & \multirow{2}{*}{$\begin{array}{l}\text { Days post } \\
\text { SIV infection }\end{array}$} & \multicolumn{2}{|c|}{$\mathrm{ID}_{50}$ in TZM-bI cells } \\
\hline & & & $\operatorname{SIV}_{\mathrm{MAC}} 251.6$ & $\mathrm{SIV}_{\text {MAC }} 251.30$ \\
\hline \multirow[t]{30}{*}{ Intravaginal (Ivag) } & \multirow[t]{5}{*}{ BC35 } & 0 & - & - \\
\hline & & 27 & 6350 & - \\
\hline & & 41 & $>43740$ & - \\
\hline & & 84 & $>43740$ & - \\
\hline & & 257 & $>43740$ & - \\
\hline & \multirow[t]{5}{*}{ CL86 } & 0 & - & - \\
\hline & & 27 & $>43740$ & - \\
\hline & & 41 & $>43740$ & - \\
\hline & & 84 & $>43740$ & - \\
\hline & & 126 & $>43740$ & - \\
\hline & \multirow[t]{5}{*}{ CL87 } & 0 & - & - \\
\hline & & 27 & 21470 & - \\
\hline & & 41 & $>43740$ & - \\
\hline & & 84 & $>43740$ & - \\
\hline & & 257 & $>43740$ & 313 \\
\hline & \multirow[t]{5}{*}{ DE50 } & 0 & - & - \\
\hline & & 27 & $>43740$ & - \\
\hline & & 41 & $>43740$ & - \\
\hline & & 84 & $>43740$ & - \\
\hline & & 136 & $>43740$ & - \\
\hline & \multirow[t]{5}{*}{ FK88 } & 0 & - & - \\
\hline & & 27 & $>43740$ & - \\
\hline & & 41 & $>43740$ & - \\
\hline & & 84 & $>43740$ & - \\
\hline & & 136 & $>43740$ & - \\
\hline & \multirow[t]{5}{*}{ GN91 } & 0 & - & - \\
\hline & & 27 & 7091 & - \\
\hline & & 41 & $>43740$ & - \\
\hline & & 84 & $>43740$ & - \\
\hline & & 257 & $>43740$ & - \\
\hline \multirow[t]{12}{*}{ Intrarectal (IR) } & \multirow[t]{5}{*}{ AE14 } & 0 & - & - \\
\hline & & 25 & 736 & - \\
\hline & & 42 & 16076 & 214 \\
\hline & & 95 & 11601 & - \\
\hline & & 236 & 3323 & - \\
\hline & \multirow[t]{5}{*}{ AP09 } & 0 & - & - \\
\hline & & 25 & 4988 & - \\
\hline & & 42 & $>43740$ & 707 \\
\hline & & 95 & $>43740$ & 1000 \\
\hline & & 236 & $>43740$ & - \\
\hline & \multirow[t]{2}{*}{ AP64 } & 0 & - & - \\
\hline & & 25 & $>43740$ & - \\
\hline
\end{tabular}

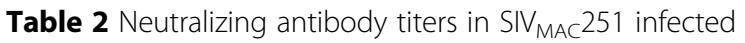
macaques (Continued)

\begin{tabular}{|c|c|c|c|}
\hline & 42 & $>43740$ & - \\
\hline & 95 & $>43740$ & - \\
\hline & 236 & $>43740$ & - \\
\hline \multirow[t]{5}{*}{ BG21 } & 0 & - & - \\
\hline & 25 & $>43740$ & - \\
\hline & 42 & $>43740$ & - \\
\hline & 95 & $>43740$ & - \\
\hline & 236 & $>43740$ & - \\
\hline \multirow[t]{5}{*}{ N107 } & 0 & - & - \\
\hline & 25 & 8981 & - \\
\hline & 42 & $>43740$ & - \\
\hline & 95 & $>43740$ & - \\
\hline & 236 & $>43740$ & - \\
\hline \multirow[t]{5}{*}{ P205 } & 0 & - & - \\
\hline & 25 & 4465 & - \\
\hline & 42 & 7942 & 93 \\
\hline & 95 & 27282 & 285 \\
\hline & 236 & $>43740$ & - \\
\hline \multirow[t]{5}{*}{ T153 } & 0 & - & - \\
\hline & 25 & 2359 & - \\
\hline & 42 & $>43740$ & - \\
\hline & 95 & $>43740$ & 24 \\
\hline & 236 & $>43740$ & - \\
\hline
\end{tabular}

Note: "-" denotes no positive responses detected for that specific time point

Immunoglobulin classes share similar functional linear Bcell epitopes

Individual 15-mer peptides (11-aa overlap) for SIV-Env, Gag and Nef antigens were used to identify functional linear B-cell epitopes using antigen specific ELISA protocol mentioned above (Figs. 4 and 5). In general, peptide-specific IgG responses were detected against multiple regions of all proteins and increased following SIV infection in both Ivag and IR inoculated macaques (Figs. 4b and 5b, f). By 73dpi all Ivag infected RMs responded to both SIV-Gag and Env PPs with 100\% responding to Env PP16 and 19 and Gag PP11 (Figs. 4b and $5 \mathrm{~b})$. Conversely, some macaques infected via the IR route did not respond to any PPs until 272dpi, when $100 \%$ of animals responded to Env PP16 (Figs. 4b and 5b). Peptide-specific IgM responses in Ivag infected macaques appeared during early infection and diminished overtime (Figs. 4c and 5c, g, i). Peptide-specific IgA responses were limited and inconsistent compared to peptide-specific IgG responses in Ivag and IR infected macaques and there were no detectable Nef or Tatspecific IgA responses (Figs. 4d and 5d). SIV infection 


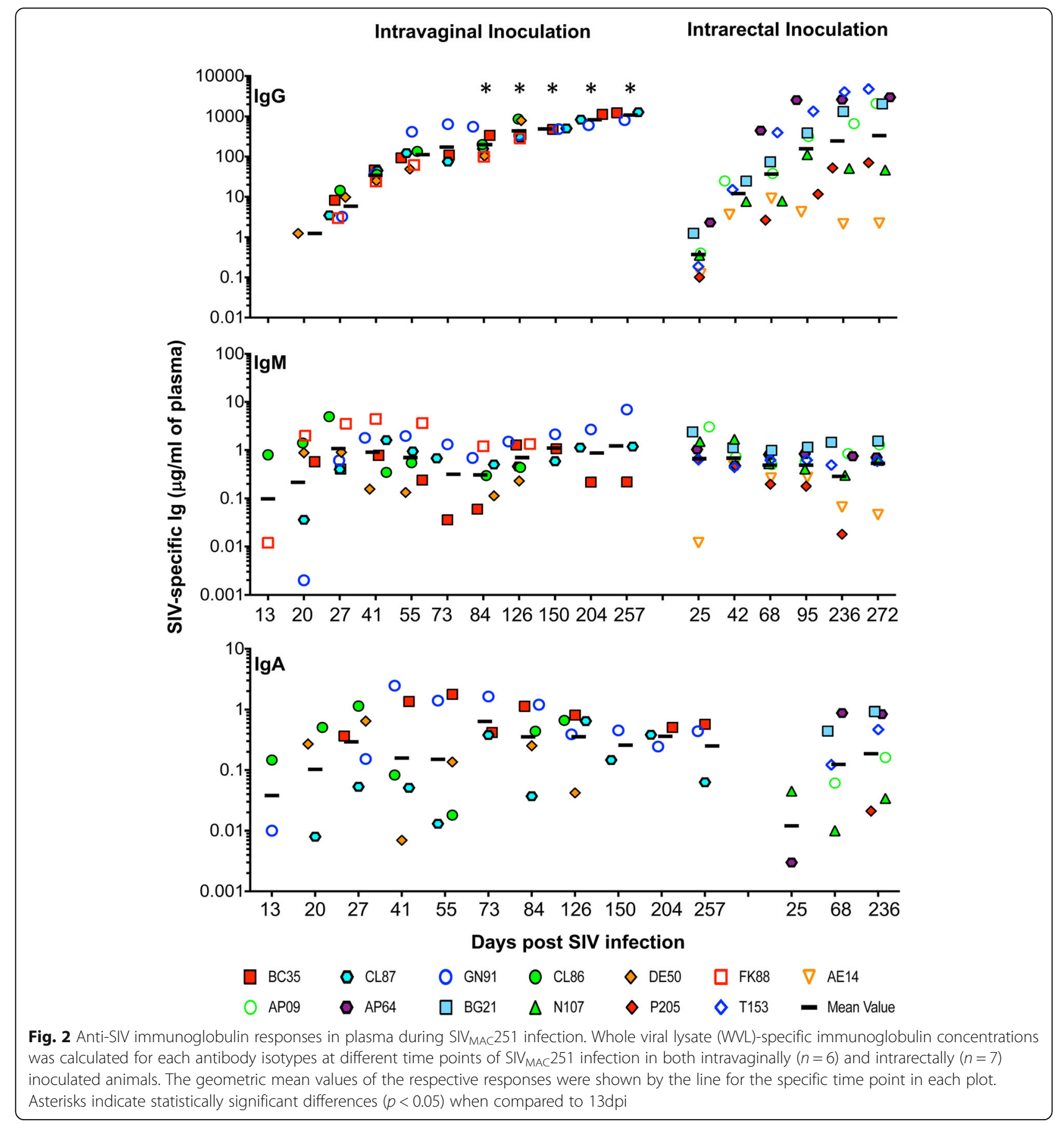

via different mucosal routes appears to induce similar systemic antigen-specific immunoglobulin responses implying vaccine targets should be similar, regardless of the route of mucosal transmission.

Overall, the majority of the three immunoglobulin classes bound the same regions of Env peptides (e.g., first 31-aa in PP16, Fig. 4a). High Ab binding was also observed for Env-PP13, V1-V3 regions of gp120, and gp41. During SIV infection, the majority of the
Env-specific IgG and IgA responses were generated against gp41, however, this was not statistically significant for either route of inoculation when compared to the binding with gp120 (Fig. 4b, $p>0.05$ ). V2-V3 of gp120 played an important role in inducing antigen-specific IgM responses.

Gag-specific (p15 and p27) immunoglobulin responses were limited, and most $\mathrm{Ab}$ responses occurred in the $\mathrm{p} 2, \mathrm{p} 1$ and highly conserved $\mathrm{p} 8$ and $\mathrm{p} 6$ regions 


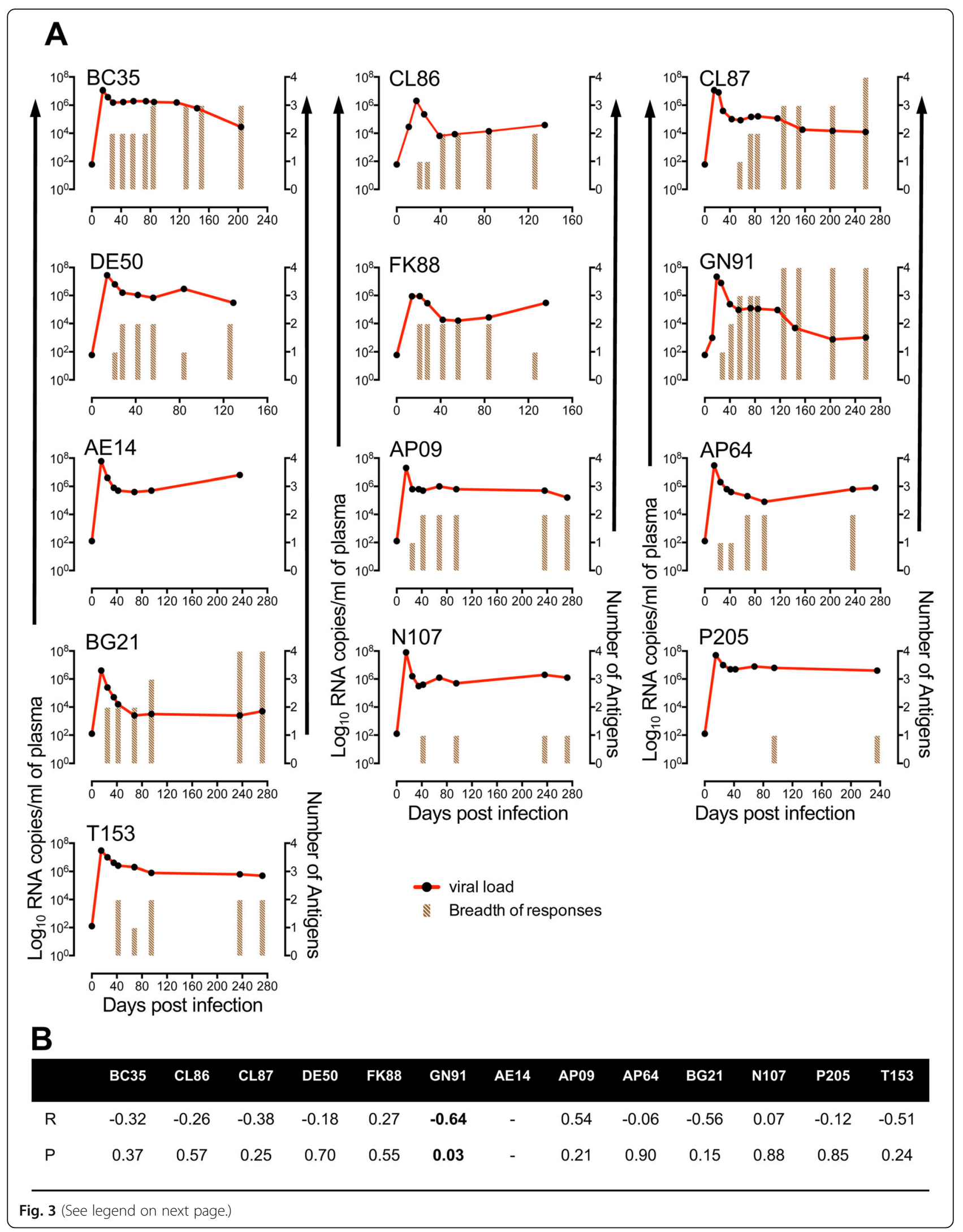


(See figure on previous page.)

Fig. 3 a Plasma viral load and number of antigens responsible for lgG responses were plotted for each macaque over the course of 257 days for intravaginally and 272 days for intrarectally SIV MAC 251 infected macaques. Each bar represents breadth (the number of antigens (Env, Gag, Tat and/or Nef) positive in any combination for lgG responses) at that specific time point. Absence of any bar represents no antigen-specific lgG responses detected for that time point. $\mathbf{b}$ Pearson coefficient of determination analysis between plasma viral load and breadth of IgG responses were shown for all macaques following $\operatorname{SIV}_{\text {MAC }} 251$ inoculation for all time points. Note, GN91 had significant correlation values that were shown in bold numbers. Animal AE14 had no detectable IgG responses upto 236dpi against any SIV antigen and therefore no value of correlation was determined. $R$ and $P$ denote Pearson $R$ and probability values respectively for each animal when correlated with plasma viral load. $P$ value $<0.05$ was considered significant

(Fig. 5a). PP11 had important B-cell epitopes that bound to IgG, IgA and IgM Abs (Fig. 5a). The Gagspecific IgM responses were similar to that of IgG and $\operatorname{IgA}$, where a moderately strong affinity for the Gag-PP7 region was detected during acute infection, however this response diminished in chronic infection (Figs. 5c \& d).

In the IR inoculated SIV-infected RMs, Nef-specific IgG responses were limited to BG21 and appeared late during infection (95dpi). However, Nef-specific IgG

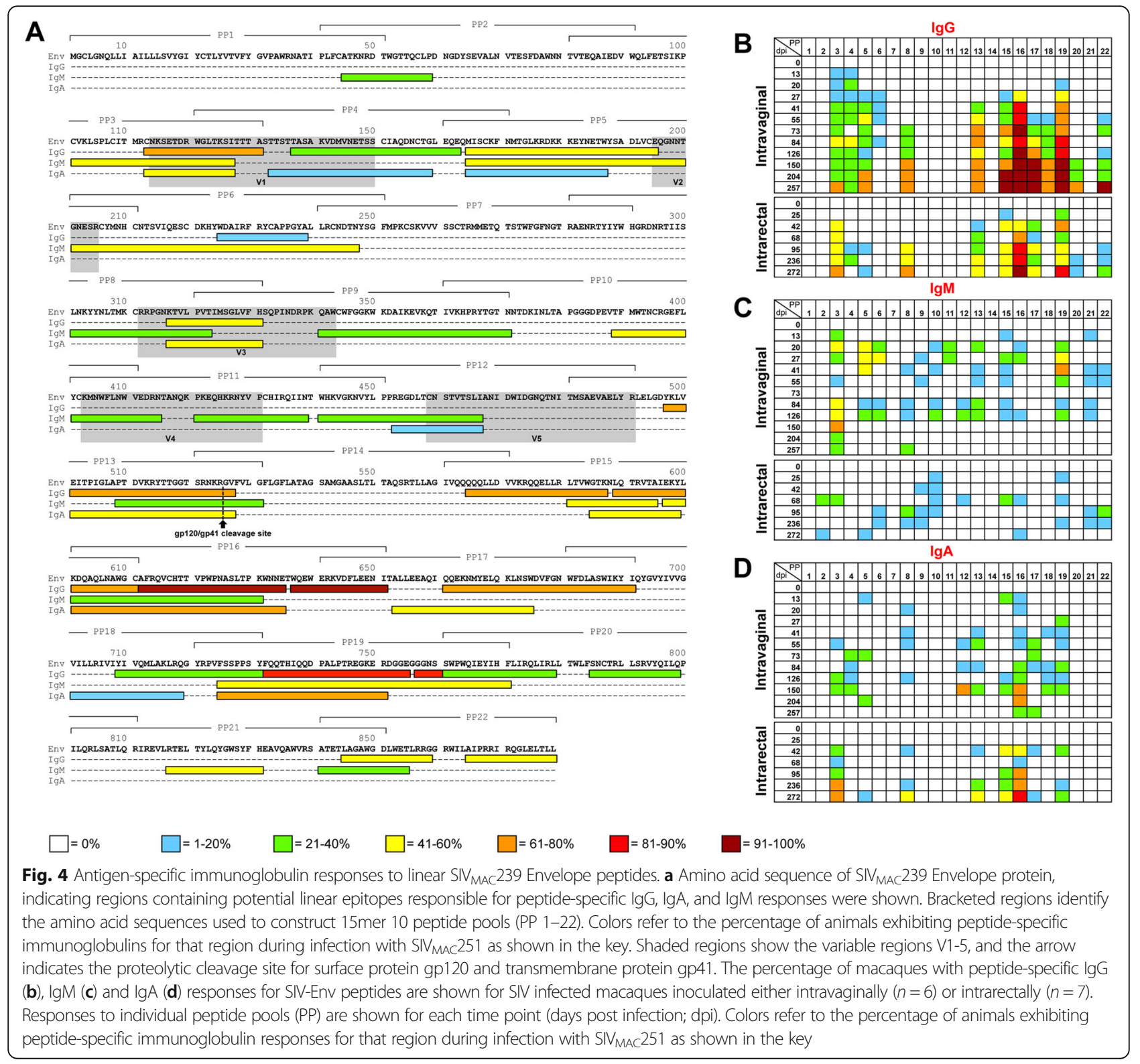




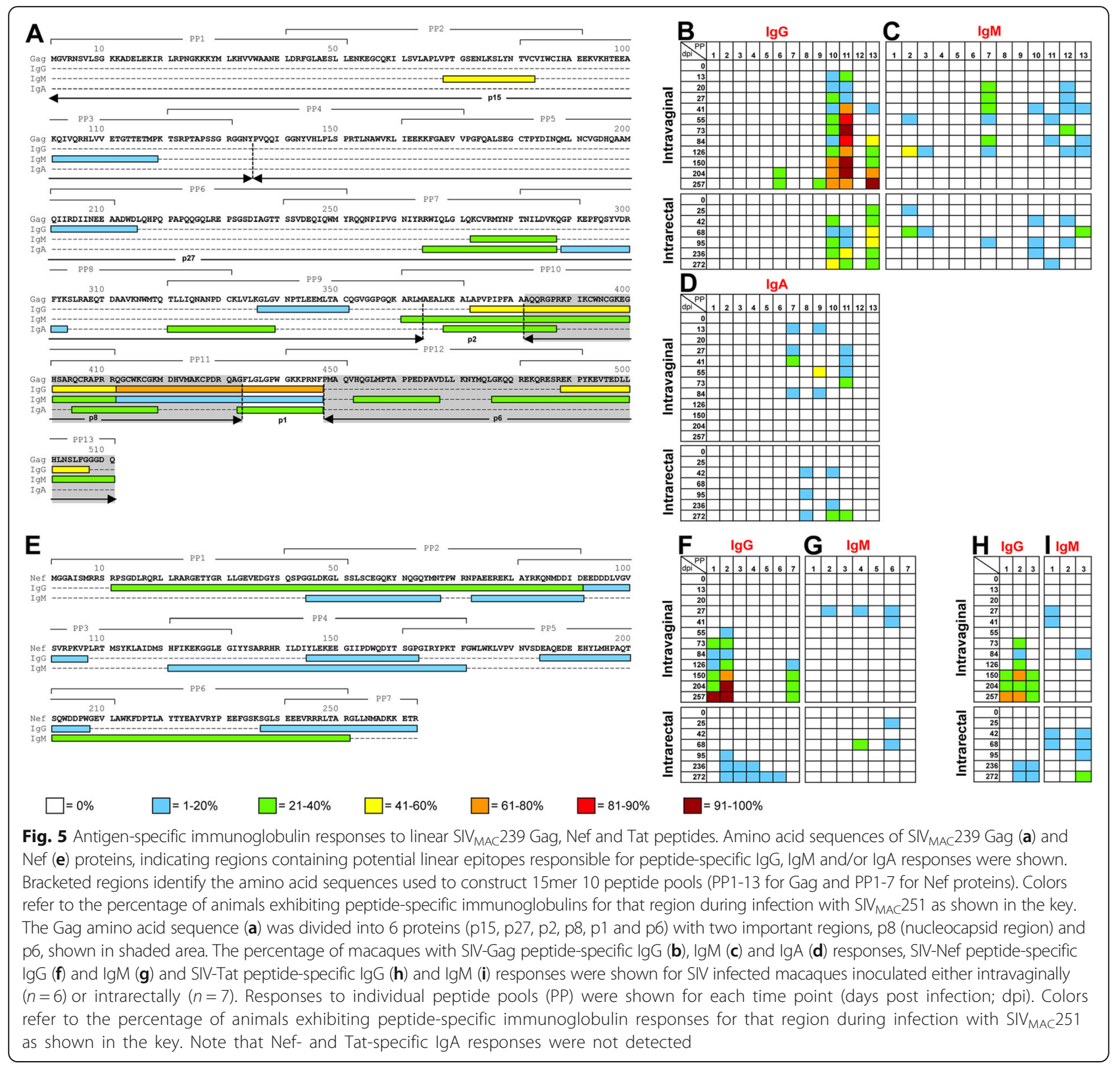

responses were detected early at 55dpi only in GN91, a RM from Ivag inoculated SIV-infected group. Moreover, Ivag inoculated SIV-infected RMs that survived upto 257dpi exhibited Nef-specific IgG responses at late chronic phase of infection (Fig. 5f). SIV-Nef epitopes varied between IgG and IgM and were scattered throughout the Nef protein (Fig. 5e).

Tat-specific responses appeared as early as $73 \mathrm{dpi}$ in Ivag infected macaques compared to IR infected macaques where the responses were detected at 236dpi. GN91 was one of the several animals with strong responses to this antigen; however, it showed no differences in the early generation of these responses when compared to other animals.

\section{Functional linear Envelope B-cell epitopes are 12 amino acid in length}

SIV-Envelope epitope mapping was performed with plasma collected from 4 chronically Ivag SIV-infected macaques (BC35, CL86, CL87 and GN91, more than 150dpi) using the antigen-specific IgG ELISA protocol as described above. Five to 12 -aa peptides from a $15 \mathrm{mer}$ SIV-Env peptide (sequence: KTVLPVTIMSGLVFH in V3 region) were synthesized commercially (GenScript, USA) and used as coating antigen at the concentration of $5 \mu \mathrm{g} / \mathrm{ml}$ to determine the exact length of a linear Bcell epitope. ELISA cutoff values were determined from SIV naïve macaques as described above. Positive IgG responses were detected when peptides with 12aa or 
greater in length were tested, which suggests that the minimum size of the functional linear epitope for eliciting antibodies was 12aa in length (Table 3). Individual 15-mer SIV-Env antigen was also used to determine the length of B-cell epitope responsible for binding responses (Fig. 4a).

\section{Discussion}

Identification of broadly neutralizing antibodies (bNAbs) directed at the Env protein provides a possible solution to generate antibody based vaccine strategies. However, all HIV vaccines assessed to date were unable to generate bNAbs. The contribution of bNAbs to the control of

Table 3 Determination of SIV-specific B-cell epitope length by ELISA

\begin{tabular}{|c|c|c|c|}
\hline Length $\left(a^{a}{ }^{a}\right)$ & Peptide Sequence ${ }^{b}$ & OD/490 & Response $^{c}$ \\
\hline 15 & KTVLPVTIMSGLVFH & 2.693 & + \\
\hline 12 & KTVLPVTIMSGL & 0.160 & - \\
\hline 12 & LPVTIMSGLVFH & 1.480 & + \\
\hline 10 & KTVLPVTIMS & 0.149 & - \\
\hline 10 & VTIMSGLVFH & 0.525 & - \\
\hline 9 & TIMSGLVFH & 0.140 & - \\
\hline 8 & KTVLPVTI & 0.146 & - \\
\hline 8 & IMSGLVFH & 0.174 & - \\
\hline 5 & KTVLP & 0.142 & - \\
\hline 5 & TVLPV & 0.211 & - \\
\hline 5 & VLPVT & 0.243 & - \\
\hline 5 & LPVTI & 0.220 & - \\
\hline 5 & PVTIM & 0.129 & - \\
\hline 5 & VTIMS & 0.243 & - \\
\hline 5 & TIMSG & 0.279 & - \\
\hline 5 & IMSGL & 0.138 & - \\
\hline 5 & MSGLV & 0.247 & - \\
\hline 5 & SGLVF & 0.192 & - \\
\hline 5 & GLVFH & 0.218 & - \\
\hline
\end{tabular}

aa denotes amino acid

${ }^{\mathrm{b}}$ Peptides created based upon sequence of SIV $_{\text {MAC } 239}$ Envelope peptide (KTVLPVTIMSGLVFH)

$\mathrm{Cu}^{\mathrm{C}}+$ " denotes positive response determined by OD/490 $\geq 0.520$ for $n=4$

Note: Grey shaded area represents the functional linear B-cell epitope (12aa in length) that are binding to plasma IgG in SIV infected animals 
early HIV-1 infection remains uncertain, as bNAbs develop relatively late in infection. Approximately $10-25 \%$ of HIV-1 infected people develop bNAbs within 3-years

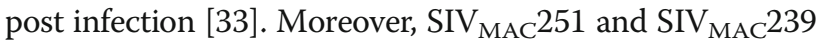
were shown to be relatively resistant to antibody-mediated neutralization by both autologous and MAbs treatment $[34,35]$. In our earlier study with either SHIV immunized or naïve $\operatorname{SIV}_{\mathrm{MAC}} 251$ challenged macaques, none of the macaques were able to generate significant levels of neutralizing Abs against either pathogenic $\operatorname{SIV}_{\mathrm{MAC}} 251$ or laboratory-adapted $\operatorname{SIV}_{\mathrm{MAC}} 251$ [23]. In this study, the presence of NAbs did not predict the outcome of the disease and moreover the occurrence of those antibodies might be too late to control the infection at that point.

GN91 was able to control pVL to approximately $1 \times 10^{3}$ RNA copies/ml of plasma and had significantly upregulated WVL-specific IgG and IgM responses compared to CL87 suggesting that binding Ab responses might be playing an important role in clearing pVL. Our overall data implies that combination of different peptide-specific IgG responses are predictive of the control of plasma viremia compared to the peptide-specific IgM and IgA responses. Our findings corroborate prior studies showing that while gp41 and gp120 show high levels of binding to IgG, there appears to be no correlation with control of early viral load, and subsequent Env-specific IgG responses had little impact on disease progression [36-38] when present without additional responses. Gag has been shown to have little antiviral function [39], however, it appears to be a strong target for antigen-specific immunoglobulin responses. The majority of immunoglobulins bind around the conserved NC, p8, and p6 regions of the Gag protein, which have several important functions in viral pathogenesis, such as viral replication, encapsulating the viral genome, aiding in reverse transcription, viral genome packaging, and viral budding [40]. While Gag is not a target for bNAbs, B-cell recognition of these highly important and conserved regions of the Gag protein may be indicative of a potential target for vaccine design. Limited data are available on the role of Nef-specific Abs in HIV disease progression. Absence of anti-Nef Abs was found to be associated with symptomatic HIV infection [41]. In our study, we identified increased and early Nef-specific IgG responses in GN91, which controlled pVL much earlier than other disease progressing RMs. Our findings, along with the recent single domain antibody study for the inhibition of Nef protein in a mouse model [42], indicate that Nef needs to be considered as an important target for a novel therapeutic approach in the prevention and control of HIV. Several studies demonstrated that Tat-specific antibodies are more common in individuals who are successfully controlling the disease, suggesting that Tat-specific Abs have a beneficial role in preventing disease progression [43-48]. In this study, we detected the presence of Tat-specific IgG in several animals, but as we have shown, it appears to be part of a large overall antigen-specific response that plays role in controlling pVL. Early induction of IgG responses against important targets and maintenance of those responses at higher magnitude might be crucial in reducing plasma viral loads and a possible predictor of disease outcome.

We also asked whether linear epitopes for antigenspecific immunoglobulins identified in this study corresponded to bNAb targets. The b12 bNAb recognizes almost exactly the same region as CD4, where these conserved regions of the CD4bs [49] fall within Env-PP10 and PP11 and induced very limited peptide-specific IgM responses (Fig. 4). However, the CD4bs is highly conformational, whereas only linear epitopes were examined in this study. Similarly, three series of bNAbs, specifically PG9, PG16 [50], and CH01-CH04 [51] target conserved conformational regions within the variable loops (V1-V3) of gp120. While these interactions have been shown to be highly conformational, the analogous V1-V3 regions in SIVMAC239 were shown to be strong targets for peptidespecific IgG, IgA and IgM responses in SIV infected macaques (Fig. 4). Two bNAbs, 2F5 and 4E10, target the highly conserved MPER region of gp41 [52]. Linear epitopes for 4E10 and 2F5 on HIV-1 strain HXB2 represent NWFNIT and ELDKWA peptide sequences respectively [52], and these regions correspond to PP17 region in SIVMAC239 (665-678aa). Seventy percent of SIV-infected macaques generated antigen-specific IgG responses to this region, and several macaques also generated antigenspecific IgA responses to this region. Therefore, Envspecific immunoglobulins bind to several linear epitopes of recently identified bNAbs, with the exception of the CD4bs. In future studies, it will be important to define the plasma viral sequence data in SIV infected animals and determine if the presence of escape variant(s) have any correlation with the antigen-specific immunoglobulin responses.

In summary, quantitative and qualitative immunoglobulin responses were detected in SIV-infected macaques, where increased IgG responses were measured specifically against the gp41 region followed by variable regions V1-V3 of gp120, and NC and p6 region of Gag protein. Antigen-specific IgM and IgA responses were more limited but targeted towards similar regions of the Env and Gag proteins. Several regions in Env protein strongly bind to immunoglobulins and are important epitopes for bNAbs. Early induction and increased breadth of antigen-specific IgG responses might be crucial to the control of plasma viral load and predictive of disease progression in SIV/HIV infection.

\section{Conclusions}

Our data strongly suggest that an early induction and increased breadth of peptide-specific IgG responses are 
indicative of disease progression. While Gag-specific responses may be argued to be an indirect indicator of HIV disease progression, recent identification of Abs against Nef and Tat proteins suggests that it may be possible to prevent and control HIV/AIDS by targeting the function of Tat and Nef proteins. Moreover, the presence of NAbs did not predict the outcome of the disease in our study where the generation of those antibodies might be too late to control the SIV infection. The experimental design does not address the role of $\mathrm{T}$-cell responses and other innate immune responses in regulating plasma viral load in these SIV-infected animals.

\section{Additional file}

Additional file 1: Table S1. Quantification of total $\lg G, \lg M$ and $\lg A$ following SIV MAC251 infection in rhesus macaques (PDF $2059 \mathrm{~kb}$ )

\section{Acknowledgements}

We thank Diganta Pan, Meredith Hunter, Pamela A. Kozlowski, Tessa Williams, Toni Penney and all animal care staff of the department of veterinary medicine for help with this study. $\operatorname{SIV}_{\text {MAC }} 251$ was obtained from the Virus Characterization, Isolation and Production Core, Division of Microbiology, Tulane National Primate Research Center, Covington, LA.

\section{Funding}

This work was supported by the National Institutes of Health grants P20 GM103458-09 and R21 Al080395 (BP) and contract \#HHSN27201100016C (DCM).

\section{Authors' contributions}

$\mathrm{BP}$ designed the research, generated and analyzed the data, and drafted the manuscript. CSK and AD generated and analyzed the data and helped in writing manuscript. PM provided part of the samples and virus for inoculation. $\mathrm{CL}$ and DM performed neutralization assays and revised the manuscript. SKS performed statistical analysis. All authors read and approved the final manuscript.

\section{Competing interests}

The authors declare that they have no competing interests.

\section{Consent for publication}

Not applicable.

\section{Ethics approval}

The study was approved by Tulane Institutional Animal Care and Use Committee (IACUC) of the TNPRC. The TNPRC is fully accredited by the Association for the Assessment and Accreditation of Laboratory Animal Care (Animal Welfare Assurance A-4499-01).

\section{Author details}

'Division of Comparative Pathology, Tulane National Primate Research Center, 18703 Three Rivers Road, Covington, LA 70433, USA. ${ }^{2}$ Tulane University School of Medicine, New Orleans 70112, LA, USA. ${ }^{3}$ Division of Microbiology, Tulane National Primate Research Center, Covington 70433, LA, USA. ${ }^{4}$ Department of Biostatistics and Bioinformatics, Tulane University, New Orleans 70112, LA, USA. ${ }^{5}$ Department of Surgery, Duke University School of Medicine, Durham, NC 27710, USA.

Received: 12 July 2016 Accepted: 17 November 2016 Published online: 01 December 2016

\section{References}

1. Moir S, Malaspina A, Ogwaro KM, Donoghue ET, Hallahan CW, Ehler LA, Liu S, Adelsberger J, Lapointe R, Hwu P, et al. HIV-1 induces phenotypic and functional perturbations of $B$ cells in chronically infected individuals. Proc Natl Acad Sci U S A. 2001;98:10362-7.
2. Malaspina A, Moir S, Ho J, Wang W, Howell ML, O'Shea MA, Roby GA, Rehm CA, Mican JM, Chun TW, Fauci AS. Appearance of immature/transitional B cells in HIV-infected individuals with advanced disease: correlation with increased IL-7. Proc Natl Acad Sci U S A. 2006;103:2262-7.

3. Moir S, Ho J, Malaspina A, Wang W, DiPoto AC, O'Shea MA, Roby G, Kottilil S, Arthos J, Proschan MA, et al. Evidence for HIV-associated B cell exhaustion in a dysfunctional memory B cell compartment in HIV-infected viremic individuals. J Exp Med. 2008;205:1797-805.

4. De Milito A, Morch C, Sonnerborg A, Chiodi F. Loss of memory (CD27) B lymphocytes in HIV-1 infection. AIDS. 2001;15:957-64.

5. Pahar B, Amedee AM, Thomas J, Dufour JP, Zhang P, Nelson S, Veazey RS, Bagby GJ. Effects of alcohol consumption on antigen-specific cellular and humoral immune responses to SIV in rhesus macaques. J Acquir Immune Defic Syndr. 2013;64:332-41.

6. Das A, Veazey RS, Wang X, Lackner AA, Xu H, Pahar B. Simian immunodeficiency virus infection in rhesus macaques induces selective tissue specific B cell defects in double positive CD21 + CD27+ memory B cells. Clin Immunol (Orlando, Fla). 2011;140:223-8.

7. Das A, Xu H, Wang X, Yau CL, Veazey RS, Pahar B. Double-positive CD21 + CD27+ B cells are highly proliferating memory cells and their distribution differs in mucosal and peripheral tissues. PLoS One. 2011;6:e16524.

8. Nguyen M, Pean P, Lopalco L, Nouhin J, Phoung V, Ly N, Vermisse P, Henin Y, Barre-Sinoussi F, Burastero SE, et al. HIV-specific antibodies but not t-cell responses are associated with protection in seronegative partners of HIV-1infected individuals in Cambodia. J Acquir Immune Defic Syndr. 2006;42:412-9.

9. Haynes BF, Gilbert PB, McElrath MJ, Zolla-Pazner S, Tomaras GD, Alam SM, Evans DT, Montefiori DC, Karnasuta C, Sutthent R, et al. Immune-correlates analysis of an HIV-1 vaccine efficacy trial. N Engl J Med. 2012;366:1275-86.

10. Hangartner L, Zellweger RM, Giobbi M, Weber J, Eschli B, McCoy KD, Harris $\mathrm{N}$, Recher $\mathrm{M}$, Zinkernagel RM, Hengartner $\mathrm{H}$. Nonneutralizing antibodies binding to the surface glycoprotein of lymphocytic choriomeningitis virus reduce early virus spread. J Exp Med. 2006;203:2033-42.

11. Braden BC, Poljak RJ. Structural features of the reactions between antibodies and protein antigens. FASEB J. 1995:9:9-16.

12. Davies DR, Padlan EA, Sheriff S. Antibody-antigen complexes. Annu Rev Biochem. 1990:59:439-73.

13. Gershoni JM, Roitburd-Berman A, Siman-Tov DD, Tarnovitski Freund N, Weiss Y. Epitope mapping: the first step in developing epitope-based vaccines. BioDrugs. 2007;21:145-56.

14. Wilson IA, Stanfield RL. Antibody-antigen interactions: new structures and new conformational changes. Curr Opin Struct Biol. 1994;4:857-67.

15. Berzofsky JA. Intrinsic and extrinsic factors in protein antigenic structure. Science. 1985;229:932-40.

16. Council NR. Guide for the care and use of laboratory animals. 8th ed. Washington: National Academy Press; 2001.

17. Loffredo JT, Maxwell J, Qi Y, Glidden CE, Borchardt GJ, Soma T, Bean AT, Beal DR, Wilson NA, Rehrauer WM, et al. Mamu-B*08-positive macaques control simian immunodeficiency virus replication. J Virol. 2007;81:8827-32.

18. Ahlers JD, Belyakov IM. Lessons learned from natural infection: focusing on the design of protective T cell vaccines for HIV/AIDS. Trends Immunol. 2010; 31:120-30.

19. Yant $\perp$, Friedrich TC, Johnson RC, May GE, Maness NJ, Enz AM, Lifson JD, O'Connor DH, Carrington M, Watkins DI. The high-frequency major histocompatibility complex class I allele Mamu-B*17 is associated with control of simian immunodeficiency virus SIVmac239 replication. J Virol. 2006:80:5074-7.

20. Mothe BR, Weinfurter J, Wang C, Rehrauer W, Wilson N, Allen TM, Allison $\mathrm{DB}$, Watkins DI. Expression of the major histocompatibility complex class I molecule Mamu-A*01 is associated with control of simian immunodeficiency virus SIVmac239 replication. J Virol. 2003;77:2736-40.

21. Wojcechowskyj JA, Yant LJ, Wiseman RW, O'Connor SL, O'Connor DH. Control of simian immunodeficiency virus SIVmac239 is not predicted by inheritance of Mamu-B*17-containing haplotypes. J Virol. 2007;81:406-10.

22. Pahar B, Wang X, Dufour J, Lackner AA, Veazey RS. Virus-specific $T$ cell responses in macaques acutely infected with SHIV(sf162p3). Virology. 2007; 363:36-47.

23. Pahar B, Lackner AA, Piatak Jr M, Lifson JD, Wang X, Das A, Ling B, Montefiori DC, Veazey RS. Control of viremia and maintenance of intestinal CD4(+) memory T cells in SHIV(162P3) infected macaques after pathogenic SIV(MAC251) challenge. Virology. 2009;387:273-84.

24. Valentine LE, Loffredo JT, Bean AT, Leon EJ, MacNair CE, Beal DR, Piaskowski SM, Klimentidis YC, Lank SM, Wiseman RW, et al. Infection with "escaped" 
virus variants impairs control of simian immunodeficiency virus SIVmac239 replication in Mamu-B*08-positive macaques. J Virol. 2009;83:11514-27.

25. Cline AN, Bess JW, Piatak Jr M, Lifson JD. Highly sensitive SIV plasma viral load assay: practical considerations, realistic performance expectations, and application to reverse engineering of vaccines for AIDS. J Med Primatol. 2005;34:303-12.

26. Pahar B, Lackner AA, Veazey RS. Intestinal double-positive CD4 + CD8+ T cells are highly activated memory cells with an increased capacity to produce cytokines. Eur J Immunol. 2006;36:583-92.

27. Pan D, Kenway-Lynch CS, Lala W, Veazey RS, Lackner AA, Das A, Pahar B. Lack of interleukin-10-mediated anti-inflammatory signals and upregulated interferon gamma production are linked to increased intestinal epithelial cell apoptosis in pathogenic simian immunodeficiency virus infection. J Virol. 2014;88:13015-28.

28. Li M, Gao F, Mascola JR, Stamatatos L, Polonis VR, Koutsoukos M, Voss G, Goepfert P, Gilbert P, Greene KM, et al. Human immunodeficiency virus type 1 env clones from acute and early subtype B infections for standardized assessments of vaccine-elicited neutralizing antibodies. J Virol. 2005;79:10108-25.

29. Van Rompay KK, Singh RP, Brignolo LL, Lawson JR, Schmidt KA, Pahar B, Canfield DR, Tarara RP, Sodora DL, Bischofberger N, Marthas ML. The clinical benefits of tenofovir for simian immunodeficiency virus-infected macaques are larger than predicted by its effects on standard viral and immunologic parameters. J Acquir Immune Defic Syndr. 2004;36:900-14.

30. Van Rompay KK, Greenier JL, Cole KS, Earl P, Moss B, Steckbeck JD, Pahar B, Rourke T, Montelaro RC, Canfield DR, et al. Immunization of newborn rhesus macaques with simian immunodeficiency virus (SIV) vaccines prolongs survival after oral challenge with virulent SIVmac251. J Virol. 2003;77:179-90.

31. Royce RA, Sena A, Cates Jr W, Cohen MS. Sexual transmission of HIV. N Engl J Med. 1997;336:1072-8.

32. Caskey M, Klein F, Lorenzi JC, Seaman MS, West Jr AP, Buckley N, Kremer G, Nogueira L, Braunschweig M, Scheid JF, et al. Viraemia suppressed in HIV-1-infected humans by broadly neutralizing antibody 3BNC117. Nature. 2015;522:487-91.

33. Stamatatos L, Morris L, Burton DR, Mascola JR. Neutralizing antibodies generated during natural HIV-1 infection: good news for an HIV-1 vaccine? Nat Med. 2009;15:866-70.

34. Johnson WE, Morgan J, Reitter J, Puffer BA, Czajak S, Doms RW, Desrosiers RC. A replication-competent, neutralization-sensitive variant of simian immunodeficiency virus lacking 100 amino acids of envelope. J Virol. 2002;76:2075-86.

35. Johnson WE, Sanford H, Schwall L, Burton DR, Parren PW, Robinson JE, Desrosiers RC. Assorted mutations in the envelope gene of simian immunodeficiency virus lead to loss of neutralization resistance against antibodies representing a broad spectrum of specificities. J Virol. 2003;77:9993-10003.

36. Allain JP, Laurian Y, Paul DA, Verroust F, Leuther M, Gazengel C, Senn D, Larrieu MJ, Bosser C. Long-term evaluation of HIV antigen and antibodies to p24 and gp41 in patients with hemophilia. Potential clinical importance. N Engl J Med. 1987;317:1114-21.

37. Binley JM, Klasse PJ, Cao Y, Jones I, Markowitz M, Ho DD, Moore JP. Differential regulation of the antibody responses to Gag and Env proteins of human immunodeficiency virus type 1. J Virol. 1997;71:2799-809.

38. Pollock BJ, McKenzie AS, Kemp BE, McPhee DA, D'Apice AJ. Human monoclonal antibodies to HIV-1: cross-reactions with gag and env products. Clin Exp Immunol. 1989;78:323-8.

39. Banerjee K, Klasse PJ, Sanders RW, Pereyra F, Michael E, Lu M, Walker BD, Moore JP. IgG subclass profiles in infected HIV type 1 controllers and chronic progressors and in uninfected recipients of Env vaccines. AIDS Res Hum Retroviruses. 2010;26:445-58.

40. Wellensiek BP, Sundaravaradan V, Ramakrishnan R, Ahmad N. Molecular characterization of the HIV-1 gag nucleocapsid gene associated with vertical transmission. Retrovirology. 2006;3:21.

41. Rezza G, Titti F, Pezzotti P, Sernicola L, Lo Caputo S, Angarano G, Lazzarin A, Sinicco A, Rossi GB, Verani P. Anti-nef antibodies and other predictors of disease progression in HIV-1 seropositive injecting drug users. J Biol Regul Homeost Agents. 1992;6:15-20.

42. Bouchet J, Basmaciogullari SE, Chrobak P, Stolp B, Bouchard N, Fackler OT, Chames P, Jolicoeur P, Benichou S, Baty D. Inhibition of the Nef regulatory protein of HIV-1 by a single-domain antibody. Blood. 2011;117:3559-68.

43. Gallo RC, Burny A, Zagury D. Targeting Tat and IFN(alpha) as a therapeutic AIDS vaccine. DNA Cell Biol. 2002;21:611-8.

44. Re MC, Furlini G, Vignoli M, Ramazzotti E, Zauli G, La Placa M. Antibody against human immunodeficiency virus type 1 (HIV-1) Tat protein may have influenced the progression of AIDS in HIV-1-infected hemophiliac patients. Clin Diagn Lab Immunol. 1996:3:230-2.

45. Re MC, Vignoli M, Furlini G, Gibellini D, Colangeli V, Vitone F, La Placa M. Antibodies against full-length Tat protein and some low-molecular-weight Tat-peptides correlate with low or undetectable viral load in HIV-1 seropositive patients. J Clin Virol. 2001;21:81-9.

46. Rezza G, Fiorelli V, Dorrucci M, Ciccozzi M, Tripiciano A, Scoglio A, Collacchi B, Ruiz-Alvarez M, Giannetto C, Caputo A, et al. The presence of anti-Tat antibodies is predictive of long-term nonprogression to AIDS or severe immunodeficiency: findings in a cohort of HIV-1 seroconverters. J Infect Dis. 2005;191:1321-4.

47. Richardson MW, Mirchandani J, Duong J, Grimaldo S, Kocieda V, Hendel H, Khalili K, Zagury JF, Rappaport J. Antibodies to Tat and Vpr in the GRIV cohort: differential association with maintenance of long-term nonprogression status in HIV-1 infection. Biomed Pharmacother. 2003;57:4-14.

48. Zagury JF, Sill A, Blattner W, Lachgar A, Le Buanec H, Richardson M, Rappaport J, Hendel H, Bizzini B, Gringeri A, et al. Antibodies to the HIV-1 Tat protein correlated with nonprogression to AIDS: a rationale for the use of Tat toxoid as an HIV-1 vaccine. J Hum Virol. 1998;1:282-92.

49. Zhou T, Xu L, Dey B, Hessell AJ, Van Ryk D, Xiang S-H, Yang X, Zhang M-Y, Zwick MB, Arthos J, et al. Structural definition of a conserved neutralization epitope on HIV-1 gp120. Nature. 2007;445:732-7.

50. Walker LM, Phogat SK, Chan-Hui P-Y, Wagner D, Phung P, Goss JL, Wrin T, Simek MD, Fling S, Mitcham JL, et al. Broad and potent neutralizing antibodies from an African donor reveal a new HIV-1 vaccine target. Science (New York, NY). 2009;326:285-9.

51. Bonsignori $M$, Hwang $K-K$, Chen $X$, Tsao C-Y, Morris L, Gray E, Marshall DJ, Crump JA, Kapiga SH, Sam NE, et al. Analysis of a clonal lineage of HIV-1 envelope V2N3 conformational epitope-specific broadly neutralizing antibodies and their inferred unmutated common ancestors. J Virol. 2011;85:9998-10009.

52. Cardoso RMF, Zwick MB, Stanfield RL, Kunert R, Binley JM, Katinger H, Burton DR, Wilson IA. Broadly neutralizing anti-HIV antibody $4 \mathrm{E} 10$ recognizes a helical conformation of a highly conserved fusion-associated motif in gp41. Immunity. 2005:22:163-73.

\section{Submit your next manuscript to BioMed Central and we will help you at every step:}

- We accept pre-submission inquiries

- Our selector tool helps you to find the most relevant journal

- We provide round the clock customer support

- Convenient online submission

- Thorough peer review

- Inclusion in PubMed and all major indexing services

- Maximum visibility for your research

Submit your manuscript at www.biomedcentral.com/submit
) Biomed Central 